\title{
Model Pengendalian Faktor Risiko Stunting pada Anak Usia di Bawah Tiga Tahun
}

\author{
Model of Stunting Risk Factor Control among Children under Three Years \\ Old
}

Erna Kusumawati, Setiyowati Rahardjo, Hesti Permata Sari

Jurusan Kesehatan Masyarakat Fakultas Ilmu-Ilmu Kesehatan Universitas Jenderal Soedirman

\begin{abstract}
Abstrak
Stunting merupakan masalah gizi, terbukti data pemantauan status gizi Kabupaten Banyumas 2012 prevalensi stunting sebesar 28,37\% dan prevalensi tertinggi $(41,6 \%)$ di Puskesmas Kedungbanteng. Tujuan penelitian untuk menganalisis faktor risiko terkait faktor anak, ibu, lingkungan terhadap stunting bawah tiga tahun (batita) agar dapat dikembangkan model pengendaliannya. Penelitian menggunakan desain kasus kontrol, populasi adalah seluruh anak usia 6 sampai 36 bulan di Puskesmas Kedungbanteng Kabupaten Banyumas selama enam bulan tahun 2013. Sampel kasus adalah 50 batita stunting, sampel kontrol adalah 50 batita status normal. Teknik pengambilan sampel kasus diambil dari tujuh desa yang terbanyak stuntingnya, sedangkan kontrol adalah batita normal tetangga terdekat kasus dengan usia yang disamakan. Pengumpulan data dengan wawancara dan pengukuran. Analisis data univariat, bivariat (uji kai kuadrat), dan multivariat (uji regresi logistik ganda). Hasil penelitian menemukan karakteristik batita stunting terkena penyakit infeksi $(82 \%)$, riwayat panjang badan lahir < 48 centimeter $(66 \%)$, riwayat pemberian ASI dan makanan pendamping ASI kurang baik (66\%), riwayat berat badan lahir rendah (8\%). Pada penelitian ini, faktor risiko stunting adalah penyakit infeksi, pelayanan kesehatan, immunisasi, pengetahuan ibu, pendapatan keluarga, ketersediaan pangan keluarga, dan sanitasi lingkungan. Faktor yang paling dominan adalah penyakit infeksi. Model pengendalian stunting melalui peningkatan pemberdayaan keluarga terkait pencegahan penyakit infeksi, memanfaatkan pekarangan sebagai sumber gizi keluarga dan perbaikan sanitasi lingkungan.
\end{abstract}

Kata kunci: Batita, pemberdayaan keluarga, penyakit infeksi, stunting, batita

\section{Abstract}

Stunting is a nutritional problem, proved by the evidence of nutritional status monitoring at Banyumas District in 2012, the prevalence of stunting was $28.37 \%$ and the highest prevalence $41.6 \%$ at Kedungbanteng Primary
Health Care. This study aimed to analyze risk factors related to child, maternal, and environmental factors toward stunting among children under three year old in 2013 in order to develop the control model. This study used case control design, the population was all children aged of six to 36 months at Kedungbanteng Primary Health Care, Banyumas District. Sample was 50 stunting children, while the control sample was 50 normal children. Sampling technique was taken from seven villages with the highest stunting number, meanwhile the control was normal children living closest to the case with similar age. Data was collected through interview and measurement. Data analysis was conducted in univariate, bivariate (chi-square test), and multivariate analyze (multiple logistic regression test). The results found that characteristics of stunting children under three years old were often suffering infectious diseases (66\%), having body length record $<48$ centimeter $(66 \%)$, bad records of breastfeeding and comlementary feeding $(66 \%)$, and record of low birth weight (8\%).Stunting risk factors in this study were infectious disease, health services, immunization, maternal knowledge, family income, family food availability, and environmental sanitation. The most dominating factor was infectious disease. The stunting control model through enhancement of family empowerment related to infectious disease prevention, utilization yard as a family nutrition source and environmental sanitation repair.

Keywords: Family empowerment, infectious disease, stunting, under three years old children

\section{Pendahuluan}

Stunting atau terhambatnya pertumbuhan tubuh merupakan salah satu bentuk kekurangan gizi yang ditandai dengan tinggi badan menurut usia di bawah stan-

Korespondensi: Erna Kusumawati, Fakultas Ilmu-Ilmu Kesehatan Univ. Jend. Soedirman Jl. dr. Soeparno Gd B Kampus Unsoed Karawang Purwokerto, No.Telp: 0281-641202,e-mail: erna_watifadhila@yahoo.com 
dar deviasi (<- 2 SD) dengan referensi World Health Organization (WHO) 2005. Stunting merupakan refleksi jangka panjang dari kualitas dan kuantitas makanan yang tidak memadai dan sering menderita infeksi selama masa kanak-kanak. ${ }^{1}$ Anak yang stunting merupakan hasil dari masalah gizi kronis sebagai akibat dari makanan yang tidak berkualitas, ditambah dengan morbiditas, penyakit infeksi, dan masalah lingkungan. ${ }^{2}$ Stunting masa kanak-kanak berhubungan dengan keterlambatan perkembangan motorik dan tingkat kecerdasan yang lebih rendah. ${ }^{3}$ Selain itu, juga dapat menyebabkan depresi fungsi imun, perubahan metabolik, penurunan perkembangan motorik, rendahnya nilai kognitif dan rendahnya nilai akademik. Anak yang menderita stunting akan tumbuh menjadi dewasa yang berisiko obesitas, glucose tolerance, penyakit jantung koroner, hipertensi, osteoporosis, penurunan performa dan produktivitas. ${ }^{4}$

Indonesia termasuk di antara 36 negara di dunia yang memberi 90 persen kontribusi masalah gizi dunia. ${ }^{5}$ Dari hasil Riset kesehatan dasar (Riskesdas) tahun 2010, prevalensi stunting pada balita yaitu $35,6 \%$, terdiri dari sangat pendek 18,5\% dan pendek 17,1\%. Angka prevalensi tersebut lebih tinggi dibandingkan angka prevalensi gizi kurang $(17,9 \%)$, gizi buruk $(13,3 \%)$ serta gizi lebih $(14 \%)$. Provinsi Jawa Tengah memiliki prevalensi stunting sebesar $33,9 \%$ yang terdiri dari $16,9 \%$ sangat pendek dan $17 \%$ pendek. ${ }^{6}$ Berdasarkan pemantauan status gizi (PSG) Kabupaten Banyumas tahun 2011, prevalensi bawah tiga tahun (batita) stunting sebesar 28,37\% dan Puskesmas Kedungbanteng prevalensi stunting sebesar $41,6 \%$ yang terdiri dari $18,8 \%$ sangat pendek dan $11,8 \%$ pendek. $^{7}$

Dari pelbagai penelitian tentang stunting dan literatur yang ada diketahui bahwa selain infeksi stunting berhubungan juga dengan defisiensi gizi (mikronutrien dan makronutrien). Terdapat beberapa zat gizi yang berkaitan dengan stunting seperti protein, zat besi, zink, kalsium, dan vitamin D, A dan C. ${ }^{8}$ Selain itu, faktor hormon, genetik dan rendahnya pengetahuan orangtua dalam pengasuhan, kemiskinan, rendahnya sanitasi lingkungan, rendahnya aksesibilitas pangan pada tingkat keluarga terutama pada keluarga miskin, rendahnya akses keluarga terhadap pelayanan kesehatan dasar, dan masih terjadi disparitas antar provinsi yang perlu mendapat penanganan masalah yang sifatnya spesifik di wilayah rawan. 6,9,10 Stunting merupakan indikator yang sensitif untuk sosial ekonomi yang buruk dan prediktor untuk morbiditas serta mortilitas jangka panjang. Stunting pada anak usia dini itu bersifat reversible. ${ }^{11}$

Berdasarkan permasalahan tersebut dan masih tingginya prevalensi stunting pada anak di bawah tiga tahun, perlu diteliti lebih lanjut faktor risiko apa saja yang menyebabkan stunting. Tujuan penelitian adalah menganalisis faktor risiko terkait faktor anak, ibu dan lingkungan terhadap kejadian stunting batita di Puskesmas Kedungbanteng, Kabupaten Banyumas agar dapat dikembangkan model untuk pengendalian faktor tersebut.

\section{Metode}

Penelitian observasional ini menggunakan desain kasus kontrol untuk mengetahui faktor yang memengaruhi stunting pada batita serta mengetahui besar risiko (nilai odds ratio) dari masing masing faktor. ${ }^{12}$ Penelitian ini dilakukan selama 6 (enam) bulan (Maret - Agustus 2013) di wilayah kerja Puskesmas Kedungbanteng, Kabupaten Banyumas. Populasi adalah semua anak usia enam sampai 36 bulan (batita), sebagai sampel kasus adalah batita yang berstatus pendek (stunting) sebanyak 50 anak, sedangkan sampel kontrol adalah batita normal tetangga terdekat kasus sebanyak 50 anak dengan usia yang disamakan. Responden adalah ibu dari batita kasus dan kontrol. Pengambilan sampel kasus adalah dengan melihat data batita yang stunting dari tujuh desa yang ada di Puskesmas Kedungbanteng, sedangkan sampel kontrol adalah balita tetangga terdekat kasus. Jika terdapat lebih dari satu kandidat sampel kontrol, maka dilakukan random.

Data diperoleh melalui wawancara menggunakan kuesioner. Faktor anak meliputi riwayat berat dan panjang badan lahir, pemberian ASI dan Makanan Pendamping ASI (MP ASI), penyakit infeksi, pelayanan kesehatan dan imunisasi, jenis kelamin, usia anak. Faktor ibu meliputi pengetahuan ibu dan pola asuh terhadap batita. Variabel pengetahuan dan pola asuh dikategorikan menjadi dua yaitu baik dan kurang baik dengan pendekatan uji normalitas. Total skor pengetahuan tidak berdistribusi normal sehingga dikategorikan baik jika skor $\geq$ median dan kurang baik jika skor $<$ median. Total skor pola asuh ibu berdistribusi normal sehingga dikategorikan menjadi baik jika skor $\geq$ mean dan kurang baik jika $<$ mean. Faktor lingkungan keluarga meliputi tinggi badan orang tua, pendidikan orang tua, pekerjaan, pendapatan, jumlah anggota keluarga, ketersediaan pangan, dan sanitasi lingkungan. Variabel sanitasi lingkungan terdiri dari beberapa pertanyaan, kemudian dari total skor dilakukan uji normalitas untuk dikategorikan menjadi baik dan kurang baik. Kuesioner sebelum digunakan dilakukan uji coba kuesioner pada 30 ibu yang mempunyai balita di Desa Banjarsari Wetan wilayah Puskesmas II Sumbang dengan karakteristik yang hampir sama dengan lokasi penelitian yaitu terdapat banyak batita stunting.

Pengukuran antropometri stunting diukur berdasarkan parameter panjang/tinggi badan menurut usia dibandingkan dengan standar antropometri WHO 2005. ${ }^{13}$ Pengukuran panjang badan untuk usia kurang dari 24 bulan atau yang belum dapat berdiri diukur panjang badan dengan menggunakan length measuring 
board dalam posisi tidur. Sedangkan pada sampel usia $\geq$ 24 bulan dan untuk orangtua dilakukan dalam posisi berdiri dengan menggunakan microtoice kapasitas ukur 2 meter dengan ketelitian 0,1 centimeter.

Pemberian ASI dan MP ASI diukur dari riwayat memberikan ASI dan MP ASI dari mulai lahir sampai saat dilaksanakan penelitian terdiri dari beberapa pertanyaan tentang ASI Eksklusif, usia pemberian, jenis dan tahapan makanan pendamping ASI (MP-ASI) kemudian dari total skor dilakukan uji normalitas untuk dikategorikan menjadi baik dan kurang baik. Penyakit infeksi adalah suatu kondisi pada saat batita diukur mengalami gangguan karena terjadinya infeksi saluran pernapasan akut (ISPA), diare, atau campak selama penelitian dengan didasarkan pada diagnosis dokter. Pelayanan kesehatan dan imunisasi diukur dari kelengkapan imunisasi dasar yaitu jumlah jenis imunisasi yang pernah diterima balita sesuai umur dan kondisi kesehatan. Pengetahuan ibu diukur dari kemampuan ibu dalam menjawab dengan benar pertanyaan yang berkaitan dengan stunting termasuk penyebab dan akibatnya. Pola pengasuhan berdasarkan perilaku ibu dalam kebiasaan mengasuh dan merawat balitanya, cara pemberian makan dan perawatan kesehatan. Ketersediaan pangan adalah kemampuan responden menjawab pertanyaan mengenai ketersediaan pangan di tingkat rumah tangga. ${ }^{14}$ Sanitasi lingkungan berdasarkan penggunaan sarana pembuangan limbah dan air minum yang sesuai standar kesehatan.

Analisis data meliputi analisis univariat, bivariat dan multivariat. Analisis univariat dengan melakukan uji distribusi frekuensi. Analisis bivariat digunakan untuk mengetahui sejauh mana hubungan antara faktor-faktor yang diduga berhubungan dengan stunting dilakukan dengan uji kai kuadrat dengan tingkat kemaknaan (nilai $\mathrm{p}=0,05$ ) dan confidence interval (CI) 95\%. Untuk melihat faktor risiko yang paling dominan dilakukan analisis multivariat regresi logistik ganda terhadap variabel hasil analisis bivariat yang memiliki nilai $\mathrm{p}<0,25$ atau secara subtansi dianggap penting berhubungan terhadap stun- ting sehingga didapatkan model akhir dengan nilai $\mathrm{p} \leq$ $0,05.15$

Penentuan model pengendalian faktor risiko didasarkan hasil analisis multivariat dikaitkan dengan kerangka pikir The United Nations Children's Fund (UNICEF) tahun 1990 tentang determinan penyebab timbulnya kekurangan gizi pada ibu dan anak. ${ }^{16}$ Kerangka pikir UNICEF digunakan karena dalam menyusun perencanaan model pengendalian atau intervensi perlu mempertimbangkan faktor determinan. Model pengendalian faktor risiko dalam penelitian ini adalah promosi multilevel dengan pendekatan multilevel approach to community health (MATCH). ${ }^{17}$ Pendekatan $M A T C H$ ini memfokuskan pada implementasi dengan perspektif sosioekologi dan mengembangkan intervensi multipel untuk mengatasi perilaku individu dan kondisi lingkungan dengan modifikasi faktor determinan, yaitu faktor anak, ibu dan lingkungan terhadap kejadian stunting batita (bawah tiga tahun). ${ }^{18}$

\section{Hasil}

Berdasarkan analisis univariat distribusi variabel independen pada kelompok kasus dan kontrol, diketahui dari faktor anak, ditemukan persentase kasus lebih banyak memiliki riwayat berat badan lahir rendah (BBLR), memiliki riwayat panjang badan lahir rendah kurang dari 48 sentimeter, mempunyai riwayat kurang baik dalam pemberian ASI dan MP-ASI, sering mengalami penyakit infeksi, kurang baik dalam pelayanan kesehatan dan imunisasi. Faktor ibu diketahui persentase pengetahuan kurang dan pola asuh anak kurang baik pada kasus lebih banyak dibandingkan pada kelompok kontrol. Faktor lingkungan persentase pada kasus yang lebih banyak adalah tinggi badan ayah ibu di bawah standar, pendidikan dasar ayah dan ibu, pekerjaan, pendapatan kelurga yang rendah, ketersediaan pangan, dan sanitasi lingkungan yang kurang baik.

Hasil analisis bivariat menunjukkan bahwa dari pelbagai faktor risiko yang diteliti, terdapat delapan faktor

Tabel 1. Hubungan Faktor Anak dengan Stunting pada Batita 6 - 36 Bulan

\begin{tabular}{|c|c|c|c|c|c|c|}
\hline Faktor Anak & Kategori & Kasus $(\%)$ & Kontrol (\%) & Nilai p & OR & CI 95\% \\
\hline \multirow[t]{2}{*}{ Riwayat berat badan lahir } & $<2.500$ gram & $4 \quad(8)$ & $0(0)$ & 0,017 & 2,09 & $1,69-2,57$ \\
\hline & $\geq 2.500$ gram & $46(92)$ & $50(100)$ & & & \\
\hline \multirow[t]{2}{*}{ Riwayat panjang badan lahir } & $\bar{K}$ urang $(<51 \mathrm{~cm})$ & $33(66)$ & $32(64)$ & 1,000 & 1,09 & $0,48-2,48$ \\
\hline & Baik $(>51 \mathrm{~cm})$ & $17(34)$ & $18(36)$ & & & \\
\hline \multirow[t]{2}{*}{ Pemberian ASI } & Kurang baik & $33(66)$ & $29(58)$ & 0,537 & 1,41 & $0,62-3,16$ \\
\hline & Baik & $17(34)$ & $21(42)$ & & & \\
\hline \multirow[t]{2}{*}{ Penyakit infeksi } & Sering sakit & $41(82)$ & $17(34)$ & 0,00 & 8,84 & $3,49-22,39$ \\
\hline & Pernah sakit & 9 (18) & $33(66)$ & & & \\
\hline \multirow[t]{2}{*}{ Pelayanan kesehatan dan imunisasi } & Baik & $25(50)$ & $12(24)$ & 0,013 & 3,17 & $1,35-7,43$ \\
\hline & Kurang & $25(50)$ & $38(76)$ & & & \\
\hline \multirow[t]{2}{*}{ Jenis kelamin } & Perempuan & $20(40)$ & $26(52)$ & 0,316 & 0,615 & $0,28-1,36$ \\
\hline & Laki - laki & $30(60)$ & $24(48)$ & & & \\
\hline \multirow[t]{2}{*}{ Usia } & Berisiko & $14(28)$ & $11(22)$ & 0,644 & 1,379 & $0,55-3,43$ \\
\hline & Tidak berisiko & $36(72)$ & $39(78)$ & & & \\
\hline
\end{tabular}


Tabel 2. Hubungan Faktor Ibu dengan Stunting pada Batita 6 - 36 Bulan

\begin{tabular}{lllllc}
\hline Faktor Ibu & Kategori & Kasus (\%) & Kontrol (\%) & Nilai p & OR (CI95\%) \\
\hline Pengetahuan ibu & Kurang & $28(56,0)$ & $14(28,0)$ & 0,008 & 3,27 \\
& Baik & $22(44,0)$ & $36(72,0)$ & & \\
Pola asuh terhadap anak & Kurang & $25(25,0)$ & $18(36,0)$ & 0,226 & 1,78 \\
& Baik & $25(25,0)$ & $32(64,0)$ & & \\
\hline
\end{tabular}

Tabel 3. Hubungan Faktor Lingkungan Keluarga dengan Stunting pada Batita 6 - 36 Bulan

\begin{tabular}{|c|c|c|c|c|c|}
\hline Faktor Lingkungan Keluarga & Kategori & Kasus & Kontrol & Nilai p & Nilai OR $(95 \%$ CI $)$ \\
\hline \multirow[t]{2}{*}{ Tinggi badan ayah } & Kurang $(<165 \mathrm{~cm})$ & $34(68,0)$ & $25(50,0)$ & \multirow[t]{2}{*}{0,104} & \multirow[t]{2}{*}{2,125} \\
\hline & Normal $(\geq 165 \mathrm{~cm})$ & $16(32,0)$ & $25(50,0)$ & & \\
\hline \multirow[t]{2}{*}{ Tinggi badan ibu } & Kurang $(<156 \mathrm{~cm})$ & $46(92,0)$ & $38(76,0)$ & \multirow[t]{2}{*}{0,056} & \multirow[t]{2}{*}{3,632} \\
\hline & Normal $(\geq 156 \mathrm{~cm})$ & $4(8,0)$ & $12(24,0)$ & & \\
\hline \multirow[t]{2}{*}{ Pendidikan ayah } & Dasar & $38(76,0)$ & $21(42,0)$ & \multirow[t]{2}{*}{$0,001^{*}$} & \multirow[t]{2}{*}{4,373} \\
\hline & Menengah dan tinggi & $12(24,0)$ & $29(58,0)$ & & \\
\hline \multirow[t]{2}{*}{ Pendidikan ibu } & Dasar & $36(72,0)$ & $23(46,0)$ & \multirow[t]{2}{*}{$0.015^{*}$} & \multirow[t]{2}{*}{3,019} \\
\hline & Menengah dan tinggi & $14(28,0)$ & $27954,0)$ & & \\
\hline \multirow[t]{2}{*}{ Pekerjaan ibu } & Tidak bekerja & $42(84,0)$ & $39(78,0)$ & \multirow[t]{2}{*}{0,610} & \multirow[t]{2}{*}{1,481} \\
\hline & Bekerja & $8(16,0)$ & $11(22,0)$ & & \\
\hline \multirow[t]{2}{*}{ Pendapatan keluarga } & Kurang dari UMK & $29(58,0)$ & $13(26,0)$ & \multirow[t]{2}{*}{$0,002 *$} & \multirow[t]{2}{*}{3,930} \\
\hline & Lebih sama dengan UMK & $21(42,0)$ & $37(74,0)$ & & \\
\hline \multirow[t]{2}{*}{ Jumlah anggota keluarga } & Kecil (< 4 orang) & $28(56,0)$ & $21(42,0)$ & \multirow[t]{2}{*}{0,230} & \multirow[t]{2}{*}{1,758} \\
\hline & Besar ( $\geq 4$ orang) & $22(44,0)$ & $29(58,0)$ & & \\
\hline \multirow[t]{2}{*}{ Ketersediaan pangan } & Kurang baik & $31(62,0)$ & $12(24,0)$ & \multirow[t]{2}{*}{$0,000^{*}$} & \multirow[t]{2}{*}{1,778} \\
\hline & Baik & $19(38,0)$ & $38(76,0)$ & & \\
\hline \multirow[t]{2}{*}{ Sanitasi lingkungan } & Kurang baik & $34(68,0)$ & $10(20,0)$ & \multirow[t]{2}{*}{$0,000^{*}$} & \multirow[t]{2}{*}{8,500} \\
\hline & Baik & $16(34,0)$ & $40(80,0)$ & & \\
\hline
\end{tabular}

Tabel 4. Model Akhir Faktor yang Berpengaruh terhadap Stunting

\begin{tabular}{lcccc}
\hline Variabel Independen & Konstanta & OR & 95\% CI & Nilai p \\
\hline Infeksi & 2,11 & 8,28 & $2,81-24,10$ & 0,000 \\
Sanitasi lingkungan & 1,86 & 6,40 & $2,01-20.37$ & 0,002 \\
Ketersediaan pangan & 1,29 & 3,64 & $1,33-10,14$ & 0,014 \\
\hline
\end{tabular}

yang terbukti berhubungan dengan terjadinya stunting pada batita. Hasil analisis bivariat secara lengkap dapat dilihat pada Tabel 1 berikut ini.

Berdasarkan Tabel 1 hasil analisis bivariat hubungan faktor anak dengan stunting didapatkan hasil kejadian stunting berhubungan secara bermakna (nilai $\mathrm{p}<0,05$ ) pada batita yang menderita penyakit infeksi ( $\mathrm{OR}=8,84$ ), dan pelayanan kesehatan dan imunisasi yang kurang baik $(\mathrm{OR}=3,17)$. Diintrepretasikan faktor anak yaitu batita yang sering sakit infeksi akan berisiko 8,84 kali untuk menderita stunting. Sedabgkan batita dengan riwayat pelayanan kesehatan dan imunisasi yang kurang baik mampu meningkatkan risiko 3,167 kali lebih besar untuk stunting dibandingkan batita dengan riwayat pelayanan kesehatan dan imunisasi yang baik.

Analisis bivariat dari faktor ibu menunjukkan hubungan bermakna (nilai $\mathrm{p}<0,05$ ) yaitu variabel pengetahuan ibu (nilai $\mathrm{p}=0,008$ ) $\mathrm{OR}=3,27$ sehingga dapat diinterpretasikan bahwa pengetahuan ibu yang kurang baik berisiko meningkatkan 3,27 kali lebih besar kejadian stunting dibandingkan dengan pengetahuan ibu yang baik (Tabel 2).

Faktor lingkungan yang diteliti diperoleh hubungan bermakna (nilai $\mathrm{p}<0,05$ ) dengan kejadian stunting batita adalah pendidikan ayah, pendidikan ibu, pendapatan keluarga, ketersediaan pangan di keluarga dan sanitasi lingkungan. Berdasarkan OR variabel yang memiliki hubungan bermakna dengan stunting dapat diinterpretasikan bahwa ayah dengan pendidikan dasar mampu meningkatkan 4,37 kali dan ibu dengan pendidikan dasar mampu meningkatkan 3,02 kali lebih besar. Pendapatan keluarga yang rendah mampu meningkatkan 3,93 kali lebih besar, ketersediaan pangan keluarga yang rendah mampu meningkatkan 1,8 kali dan sanitasi lingkungan keluarga yang rendah mampu meningkatkan 8,5 kali lebih besar untuk menghasilkan anak yang stunting (Tabel 3).

Variabel yang memiliki nilai $\mathrm{p}<0,25$ dari hasil analisis bivariat merupakan variabel yang diikutsertakan dalam analisis multivariat yaitu variabel riwayat BBLR, pelayanan kesehatan dan imunisasi, pengetahuan ibu, pola asuh ibu, tinggi badan ayah, tinggi badan ibu, pendidikan ayah, pendidikan ibu, pendapatan keluarga, ketersediaan pangan dan sanitasi lingkungan. Hasil akhir analisis multivariat dengan regresi logistik diperoleh hasil pada Tabel 4.

Berdasarkan Tabel 4 hasil analisis multivariat antara faktor risiko terhadap kejadian stunting, diperoleh tiga variabel yang menunjukkan faktor risiko yang bermakna 


\begin{tabular}{|c|c|c|c|}
\hline & & \multirow{8}{*}{ 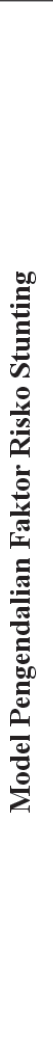 } & \multirow{6}{*}{$\begin{array}{l}\text { Level Individu (Ibu Batita) melalui } \\
\text { Pemberdayaan Ibu } \\
\text { - Pemeliharaan sanitiasi lingkungan yang } \\
\text { baik, praktik PHBS untuk keluarga dan } \\
\text { higiene personal khususnya untuk anak } \\
\text { dalam upaya untuk menurunkan dan } \\
\text { mencegah penyakit infeksi yang sering } \\
\text { diderita anak } \\
\text { - Peningkatan pengetahuan dan kesadaran } \\
\text { pangan dan gizi, keterampilan } \\
\text { mengelola pangan dan konsumsi } \\
\text { dengan gizi seimbang, sanitasi } \\
\text { lingkungan, untuk meningkatkan gizi } \\
\text { dan mencegah penyakit infeksi yang } \\
\text { sering diderita anak serta. } \\
\text { memanfaatkan pekarangan sebagai } \\
\text { sumber pangan dan gizi keluarga }\end{array}$} \\
\hline FAKTOR RISIKO & MASALAH & & \\
\hline $\begin{array}{l}\text { Penyakit Infeksi pada } \\
\text { Batita stunting (66\%) } \\
\text { yaitu (Ispa dan Diare) }\end{array}$ & & & \\
\hline $\begin{array}{l}\text { Sanitasi lingkungan, } \\
\text { sebagian besar kurang } \\
\text { baik }(52 \%)\end{array}$ & $\begin{array}{l}\text { Stunting } \\
\text { pada usia 6- } \\
36 \text { bulan }\end{array}$ & & \\
\hline $\begin{array}{l}\text { ketersediaan pangan } \\
\text { keluarga kurang }(62 \%)\end{array}$ & & & \\
\hline \multirow{3}{*}{$\begin{array}{l}\text { - Pelayanan kesehatan } \\
\text { dan imunisasi kurang, } \\
\text { - Kurangnya } \\
\text { pengetahuan ibu } \\
\text { kurang, } \\
\text { - Rendahnya pendidikan } \\
\text { orang tua } \\
\text { - Rendahnya } \\
\text { pendapatan keluarga, } \\
\text { - Sebagian besar Ibu } \\
\text { rumah tangga }\end{array}$} & & & \\
\hline & & & $\begin{array}{l}\text { Level masyarakat dengan } \\
\text { Peningkatan peran dan fungsi posyandu }\end{array}$ \\
\hline & & & $\begin{array}{l}\text { Level pelayanan kesehatan, dan } \\
\text { stakeholder perlu dilakukan intervensi } \\
\text { peningkatan status gizi melalui advokasi } \\
\text { kebijakan terkait upaya pencegahan dan } \\
\text { penanggulangan stunting pada Batita }\end{array}$ \\
\hline
\end{tabular}

Gambar 1. Model Pengendalian Faktor Risiko Stunting pada Batita

(nilai $\mathrm{p}<0,05$ ). Ketiga faktor risiko tersebut adalah penyakit infeksi, sanitasi lingkungan, dan ketersediaan pangan. Variabel yang paling dominan berhubungan dengan kejadian stunting adalah penyakit infeksi dengan nilai OR yang paling besar yaitu 8,28 artinya bahwa anak yang sering menderita penyakit infeksi berisiko mengalami stunting 8,28 kali lebih besar dibandingkan anak sehat.

Berdasarkan analisis statistik yang telah dilakukan dan kerangka pikir UNICEF tahun 1990 tentang determinan masalah gizi maka dikembangkan model promosi multilevel dengan pendekatan MATCH, ${ }^{16}$ untuk mengendalikan faktor risiko stunting (Gambar 1).

\section{Pembahasan}

Dari semua faktor yang diteliti, faktor penyakit infeksi menunjukkan nilai yang paling besar sebagai faktor risiko penyebab kejadian stunting pada batita (bawah tiga tahun). Sejalan dengan kerangka konsep UNICEF 1990 salah satu faktor penyebab langsung terjadinya masalah gizi adalah penyakit infeksi. ${ }^{16}$ Hal ini sejalan dengan penelitian Cherkley, ${ }^{19}$ menyatakan bahwa gangguan pertumbuhan linier (stunting) sering terjadi pada balita miskin di Peru rata-rata anak berusia 24 bulan tinggi badanya lebih pendek 2,5 sentimeter dari standar in- ternasional dan penyakit diare berhubungan signifikan dengan kejadian anak pendek selama masa kanak-kanak. Pada penelitian Tanziha dan Kusriadi, 20 bahwa penyakit infeksi berhubungan dengan kejadian stunting pada bat ita di Nusa Tenggara Barat.

Pada penelitian ini, penyakit infeksi yang banyak diderita batita adalah ISPA dan diare $(43,0 \%)$. Anak stunting lebih memiliki kemungkinan yang lebih besar untuk menderita penyakit infeksi ini dengan durasi waktu yang lebih lama. Juga lebih cenderung mengalami gejala sisa (sekuel) akibat infeksi umum yang akan melemahkan keadaan fisik anak. ${ }^{10}$

Faktor lingkungan yang berisiko terhadap kejadian stunting pada batita adalah sanitasi lingkungan, hal ini sejalan dengan penelitian Van der Hoek, ${ }^{21}$ yang menyatakan bahwa anak-anak yang berasal dari keluarga yang mempunyai fasilitas air bersih memiliki prevalensi diare dan stunting lebih rendah daripada anak-anak dari keluarga yang tanpa fasilitas air bersih dan kepemilikan jamban. Pada penelitian ini, risiko batita stunting yang tinggal dengan sanitasi lingkungan yang kurang baik lebih tinggi dibanding dengan sanitasi yang baik. Hal ini terjadi karena sebagian besar tempat tinggal batita belum memenuhi syarat rumah sehat, ventilasi dan pencahayaan kurang, tidak adanya tempat pembuangan sampah ter- 
tutup dan kedap air, tidak memiliki jamban keluarga, serta hal ini didukung kondisi ekonomi keluarga yang relatif rendah.

Dari analisis multivariat faktor lingkungan yang mempunyai risiko yang bermakna (nilai $\mathrm{p}<0,05$ ) terhadap stunting batita adalah ketersediaan pangan dengan uji regresi logistik didapatkan hasil nilai $\mathrm{p}=0,014$ dan $\mathrm{OR}=$ 3,64 dapat diinterpretasikan bahwa ketersediaan pangan keluarga yang rendah mampu meningkatkan risiko 3,64 kali lebih besar untuk menghasilkan anak yang stunting dibandingkan dengan ketersediaan pangan keluarga yang baik. Rendahnya ketersediaan pangan, mengancam penurunan konsumsi makanan yang beragam dan bergizi seimbang dan aman di tingkat rumah tangga. Pada akhirnya, akan berdampak pada semakin beratnya masalah gizi masyarakat, termasuk stunting pada batita. Masalah akses dan ketersediaan pangan untuk penduduk miskin merupakan gabungan dari masalah kemiskinan, kurangnya pekerjaan tetap, pendapatan tunai rendah dan tidak tetap serta terbatasnya daya beli. ${ }^{16}$ Pada tataran rumah tangga, persoalan yang menonjol dalam pemantapan ketersediaan pangan adalah masih besarnya proporsi kelompok masyarakat yang memiliki daya beli rendah, ataupun yang tidak mempunyai akses atas pangan karena berbagai sebab, sehingga mereka mengalami kerawanan pangan kronis maupun transien, jika kondisi yang mereka alami ini berkelanjutan dan berpengaruh terhadap kualitas dan kuantitas makanan yang diberikan pada anaknya yang masih dalam masa tumbuh kembang. ${ }^{22}$

Pada penelitian ini, diperoleh hasil bahwa sebagian besar $(93 \%)$ keluarga mengurangi jumlah dan kualitas pangannya dikarenakan ketidakcukupan uang untuk membeli bahan makanan, dalam hal akses pangan keluarga selain dari pangan yang dibeli juga diperoleh dari hasil pertanian dan kebun yang ada.

Analisis multivariat menunjukkan pendidikan orangtua bukan menjadi faktor risiko stunting pada batita karena meskipun setengah lebih $(56,0 \%)$ ibu memiliki pengetahuan yang baik namun tidak diikuti dengan sikap, keterampilan dan kemauan serta praktik yang membawa perubahan perbaikan gizi balita. Pada penelitian Saka, ${ }^{23}$ yang menyatakan bahwa ibu dengan pendidikan tinggi memiliki hubungan dengan pengetahuan yang baik tentang tumbuh kembang anak. Pada penelitian ini, sebagian besar pendidikan orangtua baik ayah maupun ibu, termasuk pendidikan dasar dan bekerja sebagai petani / buruh tani dan wirausaha dengan penghasilan yang relatif rendah yang berdampak pada status gizi anak. Pada penelitian Anindita, ${ }^{24}$ menyatakan bahwa tingkat pendapatan yang cukup belum tentu menjamin status gizi pada balita karena tingkat pendapatan belum tentu teralokasikan cukup untuk keperluan makan. Faktor pendidikan, pendapatan keluarga, dan pengetahuan ibu juga menentukan kemampuan keluarga untuk menerapkan pengetahuan, sumber daya dan pola perilaku untuk mempromosikan dan meningkatkan status kesehatan serta mengatasi masalah lingkungan. ${ }^{25}$

Berdasarkan hasil pembahasan faktor risiko stunting diusulkan model pengendalian faktor risiko stunting melalui pemberdayaan keluarga ditujukan pada level individu (ibu batita), level masyarakat dan level pelayanan kesehatan. Perspektif sosial memahami level ganda yang ada di masyarakat, yaitu level individu untuk membentuk perilaku, level interpersonal untuk memberikan dukungan, level masyarakat untuk membentuk norma, dan level pemerintah untuk mengubah kebijakan. ${ }^{17}$

Pada individu (ibu batita), karena ibu sebagai pembina pertama dan utama terhadap pendidikan dan kesehatan anak, dan pengelola atau penyelenggara makanan dalam keluarga, memiliki peranan yang besar dalam peningkatan status gizi anggota keluarga. Model pengendalian faktor risiko melalui peningkatan pemeliharaan sanitiasi lingkungan yang baik, praktik perilaku hidup bersih dan sehat (PHBS) untuk keluarga dan higiene personal khususnya untuk anak dalam upaya untuk menurunkan dan mencegah penyakit infeksi yang sering diderita anak. Peningkatan pengetahuan dan kesadaran pangan dan gizi, keterampilan mengelola pangan dan konsumsi dengan gizi seimbang, sanitasi lingkungan, untuk meningkatkan gizi dan mencegah penyakit infeksi yang sering diderita anak serta memanfaatkan pekarangan sebagai sumber pangan dan gizi keluar. Penelitian Monteiro, ${ }^{26}$ di Brazil menemukan bahwa prevalensi stunting pada anak balita menurun lebih dari $30 \%$, yaitu dari $37 \%$ pada tahun 1974 menjadi $7 \%$ pada tahun 2006, dengan melakukan empat prioritas penanganan di antaranya meningkatkan akses pelayanan kesehatan dan gizi yang berkelanjutan pada ibu dan anak, yaitu akses pendidikan dan informasi pada remaja putri dan perempuan, cakupan penyediaan air dan sanitasi, serta daya beli keluarga. Untuk mengejar pertumbuhan sebagian catch-up growth masih mungkin pada anak stunting yang tetap dalam lingkungan yang sama sehingga menjadi penting untuk mengidentifikasi pengembangan program untuk meningkatkan gizi dan kesehatan. ${ }^{3}$

Pada level masyarakat, dilakukan dengan peningkatan peran dan fungsi posyandu. posyandu merupakan salah satu bentuk upaya kesehatan bersumber daya masyarakat (UKBM) dalam penyelenggaraan pembangunan kesehatan guna memberdayakan masyarakat dan memberikan kemudahan kepada masyarakat dalam memperoleh pelayanan kesehatan dasar, pemantauan pertumbuhan dan perkembangan balita termasuk stunting, dan untuk mempercepat penurunan angka kematian ibu dan bayi. ${ }^{27}$ Salah satu fungsi posyandu adalah sebagai media promosi kesehatan dan gizi, pemantauan pertumbuhan balita. Promosi kesehatan adalah suatu kegiatan atau usa- 
ha menyampaikan informasi kesehatan kepada masyarakat sehingga dapat meningkatkan pengetahuan tentang kesehatan yang lebih baik. ${ }^{28,29}$ Pada level pelayanan kesehatan dan pemangku kepentingan, perlu dilakukan intervensi peningkatan status gizi melalui advokasi kebijakan terkait upaya pencegahan dan penanggulangan stunting pada batita.

\section{Kesimpulan}

Penelitian ini menunjukkan tiga faktor yang secara bersama-sama mempengaruhi stunting anak usia enam sampai 36 bulan, yaitu penyakit infeksi, ketersediaan pangan dan sanitasi lingkungan dan yang paling dominan adalah penyakit infeksi paling sering dialami adalah ISPA dan diare. Berdasarkan hasil analisis multivariat dan dikaitkan dengan kerangka pikir UNICEF tahun 1990 dan model promosi multilevel dengan pendekatan MATCH diusulkan model pengendalian faktor risiko kejadian stunting dilakukan pemberdayaan keluarga, terutama ibu batita terkait pencegahan penyakit infeksi memanfaatkan pekarangan sebagai sumber gizi keluarga dan sanitasi lingkungan. Pada level masyarakat dengan peningkatan peran dan fungsi posyandu dan pada level pelayanan kesehatan perlu dilakukan intervensi peningkatan status gizi melalui advokasi kebijakan terkait upaya pencegahan stunting pada batita.

\section{Saran}

Untuk mengendalikan stunting pada batita, perlu peningkatan pemberdayaan keluarga terkait pencegahan penyakit infeksi melalui perbaikan pola asuh makan dan pola asuh kesehatan, peningkatan ketersedian pangan melalui pemanfaatan pekarangan sebagai sumber pangan dan gizi keluarga serta perbaikan sanitasi lingkungan.

\section{Daftar Pustaka}

1. Shrimpton R, Victora CG, de Onis M, Lima RC, Blossner M, Clugston G. Worldwide timing of growth faltering: implications for nutritional interventions. Pediatrics [serial on Internet]. 2001 [cited 2014 Jun 5]; 107(5): e75-e. Available from: http://pediatrics.aappublications.org/ content/107/5/e75.short

2. Semba RD, de Pee S, Sun Kai, Sari M, Akhter N, Bloem MW. Effect of parental formal education on risk of child stunting in Indonesia and Bangladesh: a cross-sectional study. Lancet [serial on Internet]. 2008 [cited 2014 Jul 5]; 371: $322-8$. Available from: http://www.sciencedirect.com/science/article/pii/S014067360860169;

3. Crookston BT, Mary EP, Stephen CA, Ty TD, Ray MM,6 Joseph BS, Christina AP and Kirk AD. Children who recover from early stunting and children who are not stunted demonstrate similar levels of cognition. J Nutr [serial on Internet]. 2009 [cited 2014 Aug 4], 1996-2001. Available from: http://jn.nutrition.org/content/ 140/11/1996.short

4. Mandal GC, Bose K, Bisai S, Ganguli S. Undernutrition among Integrated Child Development Services (ICDS) scheme children aged 26 years of Arambag, Hooghly District, West Bengal, India: A serious public health problem. Italian Journal of Public Health [serial on Internet]. 2008 [cited 2014 Aug 6]; 5(1). Available from: http://ijphjournal.it/article/view/5852

5. United Nations System Standing Committe on Nutrition (UN-SC on Nutrition). Accelerating the reduction of maternal and child undernutrition. [monograph on the Internet]. SCN News no 36, 2008 [cited 2013 Jul 9]. Available from: http://www.unscn.org/layout/modules/resources/files/scnnews36.pdf

6. Badan Penelitian Dan Pengembangan Kesehatan. Riset kesehatan dasar (RIKESDAS) tahun 2010: Jakarta: Kementerian Kesehatan Republik Indonesia: 2010

7. Dinas Kesehatan Kabupaten Banyumas. Laporan pemantauan status gizi balita tahun 2011. Purwokerto; Dinas Kesehatan Kabupaten Banyumas: 2011.

8. de Onis M, Onyango AW, Borghi E, Garza C, Yang H. Comparison of the World Health Organization (WHO) child growth standards and the national center for health statustics/WHO international growth reference: implications for child health programmes. Public Health Nutr [serial on Internet]. 2006 [cited 2014 Aug 6]; 9(07): 942-7 [cited 2014 Aug 13]. Available from: http://journals.cambridge.org/download.php? file=\%2FPHN $\% 2$ FPHN9_07\%2FS1368980006001534a.pdf\&code $=$ bc 54f79968ec2d59535dff80e4f96db5.

9. EL Taguri A, Betilma I, Mahmud SM, Momem Ahmed A, Goulet O, Galan P, et al. Risk factors for stunting among under-fives in Libya. Publ Health Nutr [cited 2014 October 15]. 2009; 12 (08): 1141-9 [serial on Internet]. Available from: http://journals.cambridge.org/ download.php? file = \% 2 F P H N \% 2 F P H N 12 _ $08 \% 2$ FS1368980008003716a.pdf $\&$ code $=67 \mathrm{a} 2 \mathrm{e} 4914 \mathrm{e} 63 \mathrm{bfda} 535 \mathrm{dff} 80 \mathrm{e} 4 \mathrm{f} 96 \mathrm{~d}$ b5.

10. Gibney MJ. Gizi kesehatan masyarakat. Andry H, Palupi, W, perterj. Jakarta: Penerbit Buku Kedokteran ECG; 2002

11. Sedgh G, M. Guillermo H, Penelope N, Alawia el A, Wafaie WF. Dietary vitamin A intake and nondietary factors are associated with reversal of stunting in children. Am Soc Nutr Sci [serial on the Internet]. 2000 [cited 2015 Aug 12]. Available from: http://jn.nutrition.org/content/130/10/2520.short.

12. Sugiyono. Metode penelitian kuantitatif, kualitatif. Alfabeta: Bandung; 2010.

13. Kementerian Kesehatan Republik Indonesia. Keputusan Menteri Kesehatan Republik Indonesia No.1995/MENKES/SK/XII/2010 tentang standar antropometri penilaian status gizi anak. Jakarta; 2011. Direktorat Jenderal Bina Gizi dan Kesehatan Ibu dan Anak

14. Gery B. Guide to measuring household food security. USDA: Alexandria; 2000

15. Basuki B. Aplikasi metode kasus kontrol. Jakarta: Bagian Kedokteran Komunitas Fakultas Kedokteran Universitas Indonesia; 2000.

16. Badan Perencanaan Pembangunan Nasional. Rencana Aksi Nasional Pangan dan Gizi 2011-2015. Jakarta: Bappenas; 2011.

17. Fertman CI, Allensworth DD, eds. Health promotion programs: from theory to practice, San Fransisco: Jossey Bass A Wiley Imprint; 2010

18. Davies M, MacDowall W, eds. Health promotion theory: understanding public health. Bekshire: Open Univy Pressersit; 2006

19. Checkley W, Epstein LD, Gilman RH, Cabrera L, Black RE. Effects of acute diarrhea on linear growth in Peruvian children. Am J Epidemiol 
[serial on Internet]. 2003 [cited 2014 Jul 26]; 157 (2). Available from: http://aje.oxfordjournals.org/content/157/2/166.full.pdf+html

20. Tanziha I, Kusriadi. Faktor-faktor yang mempengaruhi kejadian stunting pada balita di Kabupaten Lombok Tengah Provinsi Nusa tenggara Barat. Jurnal Ilmiah Agropolitan. 2010; 3 (2).

21. Van der Hoek W, Feenstra. SG, Konradsen F. Availability of irrigation water for domestic use in pakistan: its impact on prevalence of diarrhoea and nutritional status of children. Journal of Health Population and Nutrition [serial on internet]. 2002 [cited 2014 Aug 5]: 77-84. Available from: http://www.jstor.org/ discover/10.2307/23498727? sid= $21105796087873 \&$ uid $=2 \&$ uid $=4$

22. Dewan Ketahanan Pangan. Kebijakan umum ketahanan pangan 20062009. Jurnal Gizi dan Pangan. 2006; 1(1): 57-63.

23. Saaka M. Relationship between mothers' nutritional knowledge in children practices and the growth of children living in impoverished rural communities. J Health Pop Nutr [serial on Internet]. 2014 [cited 2014 Oct 5]; 32(2): 237-48. Available from: http://www.ncbi.nlm.nih.gov/ pmc/articles/PMC4216960/

24. Anindita P. Hubungan tingkat pendidikan ibu, pendapatan keluarga, kecukupan protein dan zinc dengan stunting (pendek) pada balita usia 6-
35 bulan di Kecamatan Tembalang kota Semarang. Jurnal Kesehatan Masyarakat. 2012; 1(2): 617-26.

25. Reyes H, Perez_cuevas R, Sandoval A, Castillo RI, Santos JI, et.al. The family as a determinant of stunting in children living in conditions of extreme poverty; a case control studi. BMS Public Health [serial on Internet]. 2004 [cited 2014 Aug 5]; 4(1):57. Available from: http://www.biomedcentral.com/1471-2458/4/57

26. Monteiro CA, Benicio MHD, Conde WL, Konno S, Lovadino AL, Barno AJ. Narrowing socioeconomic inequality in child stunting: The Brazilian Experience, 1974-2007. Bull WHO [serial on the Internet]. 2010 [ cited 2014 Aug 12]; 88: 305-11. Available from: http://www.who.int/bulletin/volumes/88/4/09-069195/en/

27. Kementerian Kesehatan Republik Indonesia. Pedoman kader seri kesehatan anak. Jakarta: Kementerian Kesehatan Republik Indonesia; 2010.

28. Notoadmodjo. Pendidikan dan perilaku kesehatan. Jakarta: Rineka Cipta; 2007.

29. Kusumawati E, Rahadrjo S. Pengaruh pelayanan kesehatan terhadap gizi buruk usia 6-24 bulan. Kesmas: Jurnal Kesehatan Masyarakat Nasional. 2012; 6 (4): 158-62. 